\title{
Satellite Image Atlas of Glaciers of the World
}

Most mountain glaciers worldwide have been retreating since the late 1800s (at the end of the "Little Ice Age"), and global sea level has risen about 30 centimeters since then. Glaciers vary in size in response to changes in global and regional climates (such as warmer summers). The U.S. Geological Survey (USGS) studies the complex links among glacier variation, climate change, and global sea level.

Sea-level changes, especially in densely populated, low-lying coastal areas and on islands, have significant effects on human activities and facilities. The present volume of the Earth's glacier ice, if totally melted, represents about 80 meters in potential sea-level rise. About 200 meters is the range of sea-level changes that can be caused by water being frozen in glaciers during an ice age (glacial stage) or melted during an interglacial stage. For example, during the last glacial maximum (LGM), about 21,000 years ago, sea level is estimated to have been 125 meters lower than it is today. During a warmer climatic interval in the last interglacial stage, about 125,000 years ago, sea level was about 6 meters higher than it is today; during an even warmer interval about 2.2 million years ago, sea level is estimated to have been 25 to 50 meters higher.

A thorough global baseline study of the areal extent of existing glaciers (fig. 1) is required before scientists can assess the magnitude of glacier change that is forecast to occur worldwide during the 21 st century. Satellite images (figs. 2-5) can be used to inventory glaciers and to monitor changes in their areal extent over time.

In 1978, the USGS began the preparation of the 11-chapter USGS Professional Paper 1386, "Satellite Image Atlas of Glaciers of the World." Between 1979 and 1981, optimum satellite images were distributed to a team of 70 scientists, representing 25 nations and 45 institutions, who agreed to author sections of the Professional Paper concerning either a geographic area (chapters B-K) or a glaciological topic (included in Chapter A).

The scientists used Landsat 1, 2, and 3 multispectral scanner (MSS) images and Landsat 2 and 3 return beam vidicon (RBV) images to inventory the areal occurrence of glacier ice on our planet within the boundaries of the spacecrafts' coverage (between about $82^{\circ}$ north and south latitudes). Some later contributors also used Landsat 4 and 5 MSS and Thematic Mapper, Landsat 7 Enhanced Thematic MapperPlus (ETM+), and other satellite images.

In addition to analyzing images of a specific geographic area, each author was asked to summarize up-to-date information about the glaciers within each area and compare their present-day areal distribution with reliable historical information (from published maps,

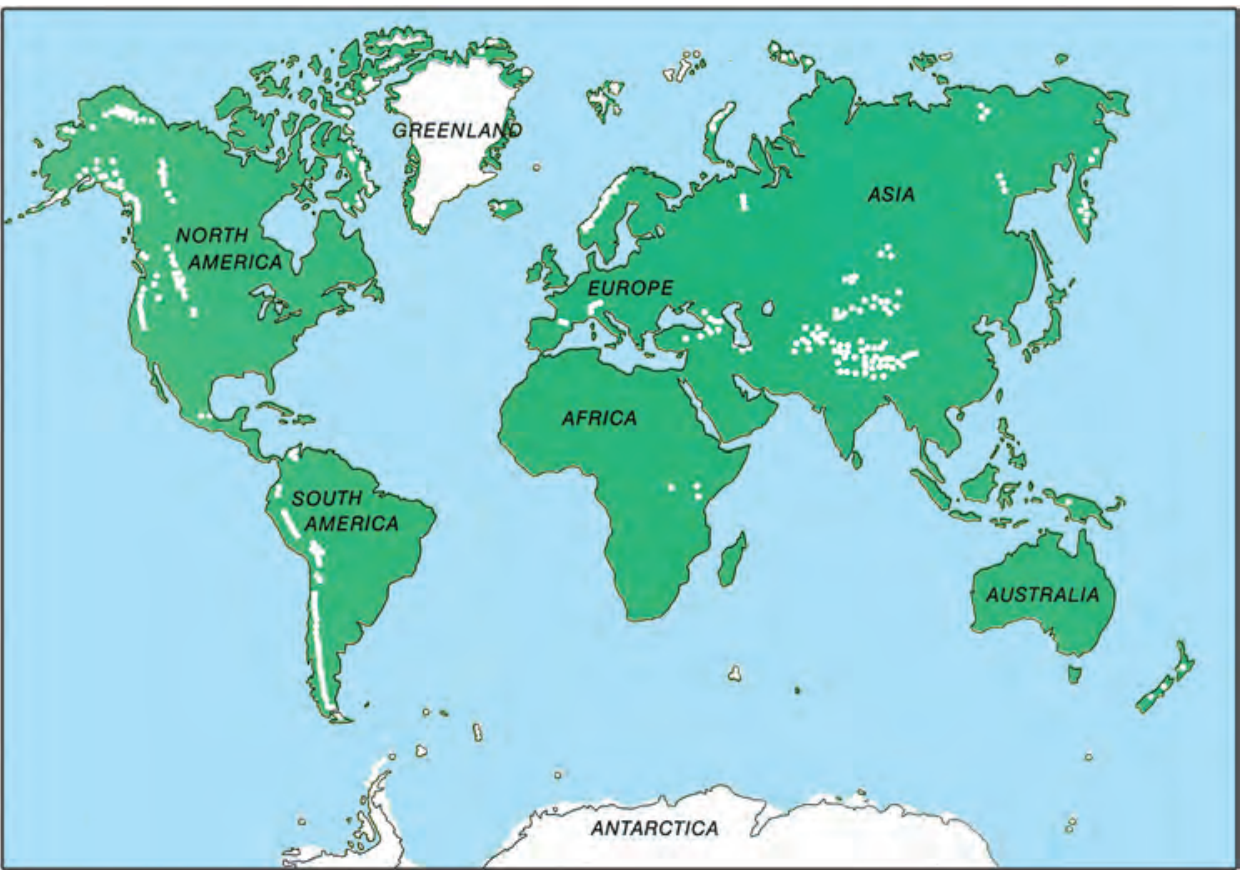

Figure 1. White areas show ice sheets and other glaciers around the world. The white spots in the oceans are islands where glaciers are found. Reproduced from National Geographic World (February 1977, no. 18, p. 6) with permission.

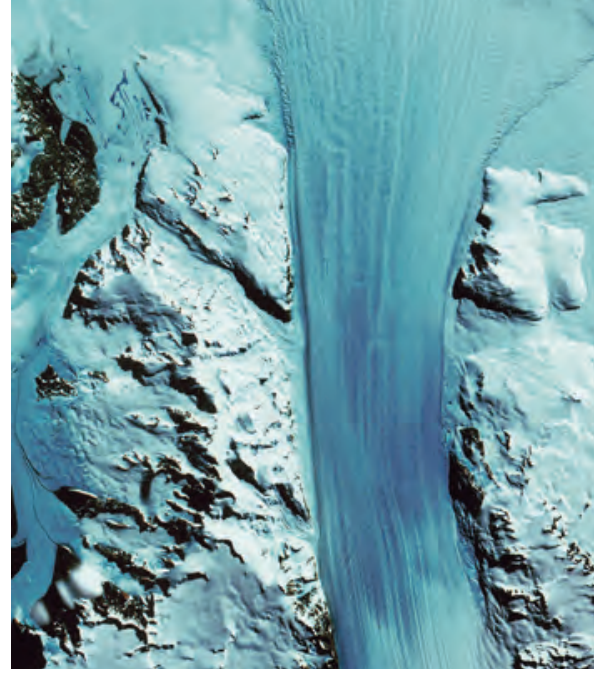

Figure 2. Landsat 1 MSS image of the Byrd Glacier where it joins the Ross Ice Shelf. From USGS Professional Paper 1386-B, Antarctica, fig. 23, p. B27.

reports, and photographs) about their past extent. Because of the limitations of Landsat MSS images for delineating or monitoring small glaciers in some geographic areas (the result of inadequate spatial resolution, lack of suitable seasonal coverage, or absence of coverage), some information on the areal distribution of small glaciers was derived from ancillary sources, including later satellite images with higher spatial resolution.

Completion of the atlas will provide an accurate regional inventory of the areal extent of glaciers on our planet during a relatively narrow time interval (1972-1981). This global "snapshot" of glacier extent is already being used for comparative analysis with previously published maps and aerial photographs, as well as with new maps, satellite images (for example, Advanced Spaceborne Thermal Emission and Reflection Radiometer (ASTER), Landsat 7 ETM+, RADARSAT), and aerial photographs, to determine the areal fluctuation of glaciers in response to natural or human-induced changes in the Earth's climate. For example, sequential Landsat 4, 5, and 7 and RADARSAT images have documented major changes in the coastal regions of Antarctica. See USGS Fact Sheets FS 2005-3055, "CoastalChange and Glaciological Maps of Antarctica " at [http://pubs.usgs.gov/fs/2005/3055/] and FS-017-02, "Coastal-Change and Glaciologic Maps of the Antarctic Peninsula" at [http:// pubs.usgs.gov/fs/fs17-02/]. See also the USGS Website at [http://www.glaciers.er.usgs.gov/]. 


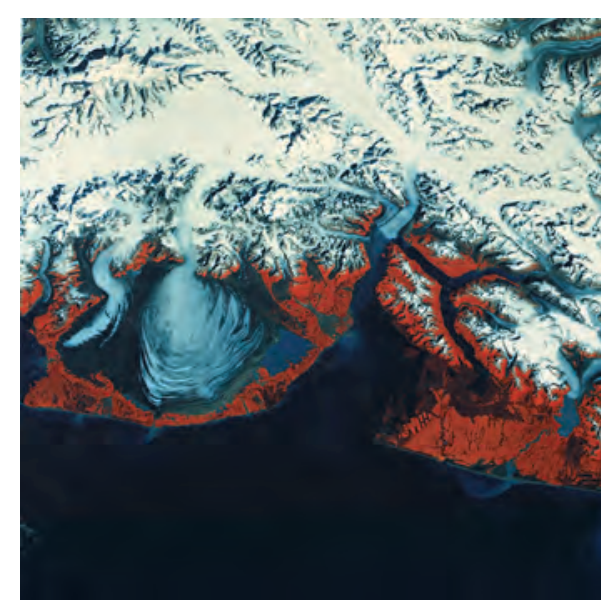

Figure 3. Landsat 2 MSS image of Malaspina Glacier, Alaska. From USGS Professional Paper 1386-K, Glaciers of Alaska, fig. 144, p. K160.

Chapter A of USGS Professional Paper 1386 (The State of the Earth's Cryosphere at the Beginning of the 21st Century: Glaciers, Global Snow Cover, Floating Ice, and Permafrost and Periglacial Environments) contains a synthesis of chapters B-K, a map/ poster of "The Earth's Dynamic Cryosphere," and a comprehensive overview of all aspects of the cryosphere. The next 10 chapters, B-K, are arranged geographically (table 1) and present glaciological information on each of the Earth's glacierized regions.

Table 1. Topics and publication dates of USGS Professional Paper 1386, chapters A-K. [Chapters A-D include supplemental maps folded in a pocket, as indicated in column 2 by "w/maps(s)." Chapters A and D are not yet available]. For status of all chapters see [http://pubs.usgs.gov/pp/p1386/].

\begin{tabular}{cll}
\hline Chapter & $\begin{array}{l}\text { Date } \\
\text { Published }\end{array}$ \\
\hline A & $\begin{array}{l}\text { State of the Earth's } \\
\text { Cryosphere w/map and } \\
\text { 8 supplemental notes }\end{array}$ & 2013 \\
\hline B & Antarctica w/maps ${ }^{1}$ & 1988 \\
\hline C & Greenland w/map ${ }^{2}$ & 1995 \\
\hline D & Iceland w/map & in press \\
\hline E & Continental Europe ${ }^{3}$ & 1993 \\
\hline F & Asia ${ }^{2}$ & 2010 \\
\hline G & Turkey, Iran, and Africa ${ }^{2}$ & 1991 \\
\hline H & $\begin{array}{l}\text { Irian Jaya (Indonesia) } \\
\text { and New Zealand }\end{array}$ & 1989 \\
\hline I & South America $^{2}$ & 1998 \\
\hline J & North America $^{2}$ & 2002 \\
\hline K & Alaska $^{2}$ & 2008 \\
\hline
\end{tabular}

${ }^{1}$ Web accessible: http://pubs.usgs.gov/pp/p1386b/

${ }^{2}$ Web accessible: http://pubs.usgs.gov/pp/p1386/[add chapter letter]

${ }^{3}$ Excluding the European part of the former Soviet Union, which is included in Chapter F (Asia)

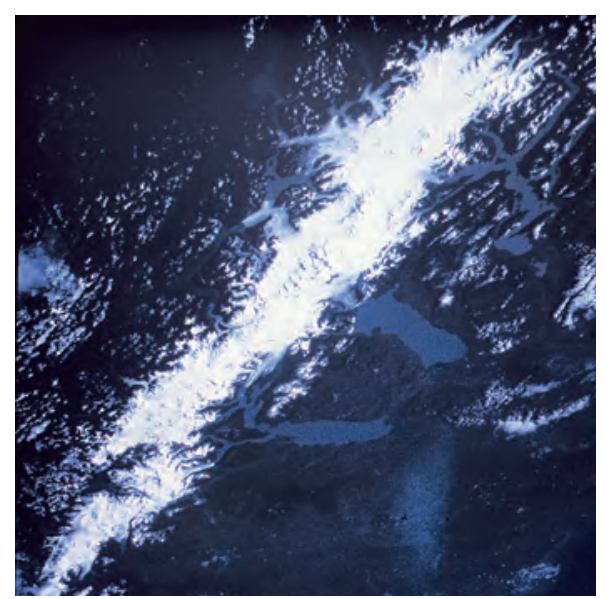

Figure 4. Salyut-6 photograph of the Southern Patagonian Ice Field, Chile and Argentina. From USGS Professional Paper 1386-I, Glaciers of South America, fig. 31, p. I165.

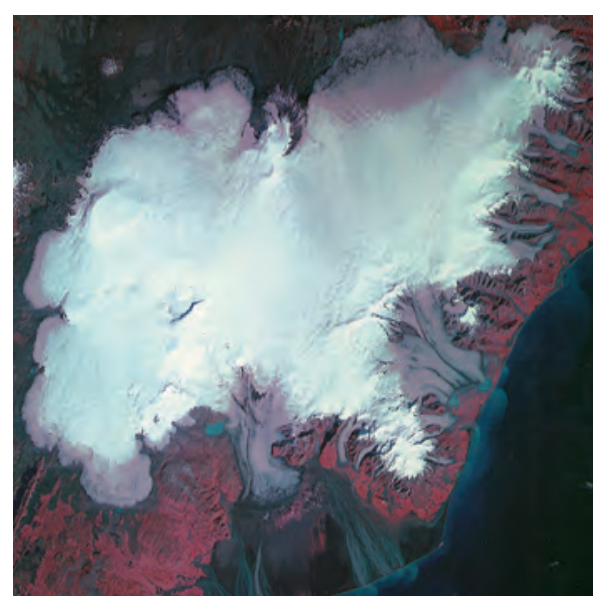

Figure 5. Digitally enhanced Landsat $1 \mathrm{MSS}$ image of Iceland's largest (8,100 square kilometers) ice cap, Vatnajökull. From USGS Professional Paper 1386-D, Glaciers of Iceland. See also USGS Professional Paper 1746, fig. 188, p. 197 in Geographic Names of Iceland's Glaciers: Historic and Modern [http://pubs.usgs.gov/pp/1746/].

\section{Foreword to the Volume}

On 23 July 1972, the first Earth Resources Technology Satellite (ERTS 1, or Landsat 1) was successfully placed in orbit. The success of Landsat inaugurated a new era in satisfying mankind's desire to better understand the dynamic world upon which we live. Space-based observations have become an essential means for monitoring changes in local, regional, and global environments.

The short- and long-term cumulative effects of processes that cause significant changes on the Earth's surface can be documented and studied by repetitive Landsat and other satellite images. Such images provide a permanent historical record of the surface of the planet; they also make possible comparative two- and three-dimensional measurement of change over time. This Professional Paper demonstrates the importance of the application of Landsat images to global studies by using them to determine the 1970's distribution of glaciers on the planet. As images become available from future satellites, the new data will be used to document global changes in glacier extent by reference to the baseline Landsat image record of the 10-year period 1972 to 1981

Although many geological processes take centuries or even millennia to produce obvious changes on the Earth's surface, other geological phenomena, such as glaciers and volcanoes, cause noticeable changes over shorter periods. Some of these phenomena can have worldwide impact and often are interrelated. Explosive volcanic eruptions, such as the 1991 Mount Pinatubo, Philippines, eruption, can produce dramatic short-term effects on the global climate. Natural or culturally induced processes can cause global climatic cooling or warming. Glaciers respond to such warming or cooling periods by decreasing or increasing in size, which in turn causes sea level to rise or fall.

As our understanding of the interrelationship of global processes improves and our ability to assess changes caused by these processes develops further, we will learn how to use indicators of global change, such as glacier variation, to manage more wisely the use of our finite land and water resources. This USGS Professional Paper series is an excellent example of the way in which we can use technology to provide needed earth-science information about our planet. The international collaboration represented by this report is also an excellent model for the kind of cooperation that scientists will increasingly find necessary in the future in order to solve important Earth-system science problems on a global basis.

Marcia K. McNutt, Director U.S. Geological Survey

\section{For more information, please contact:}

Dr. Richard S. Williams, Jr.,

Emeritus Geologist

U.S. Geological Survey

Woods Hole Coastal and Marine

Science Center

384 Woods Hole Road

Woods Hole, MA 02543-1598

e-mail: geoinfo@comcast.net

The Satellite Image Atlas of Glaciers of the World is a multinational effort of the U.S. Geological Survey's Global Change Research Program, a component of 13 interagency Federal U.S. Climate Change Science Program [http://www.climatescience.gov/] of which the U.S. Department of the Interior is a member.
Jane G. Ferrigno, Emerita Geologist

U.S. Geological Survey

926A National Center

12201 Sunrise Valley Drive

Reston, Va 20192-0002

e-mail: jane.ferrign@usgs.gov 